\title{
The Antecedent and Consequences of Brand Image in a Low- Priced Cosmetic Brand of South Korea: The Moderating Effect of Gender
}

\author{
Ki-Han Chung ${ }^{1}$, Ji-Eun $\mathrm{Yu}^{1}$, Wonjong $\mathrm{Kim}^{1}$ and Jae-Ik Shin ${ }^{2 *}$ \\ ${ }^{1}$ Department of Business Administration, Gyeongsang National University, \\ 501, Jinju-Daero, Jinju 660-701, South Korea \\ ${ }^{2}$ Department of E-Business, Gyeongnam National University of Science and \\ Technology, 33 Dongjin-Ro, Jinju 660-758, South Korea \\ *Corresponding Author: sji@gntech.ac.kr
}

\begin{abstract}
We performed a study to investigate the influence that brand image has on customer loyalty of a low-priced cosmetic brand through perceived value and customer satisfaction, as well as to examine the moderating role of gender. Appropriate measures were developed based on previous studies and tested on 234 consumers of Gyeongnam province in South Korea with a cross-sectional questionnaire survey. The results of the empirical analysis showed that perceived value positively affects brand image and customer satisfaction. Brand image positively influences customer loyalty but does not influence customer satisfaction. Customer satisfaction has a positive effect on customer loyalty. The moderating effects of gender between perceived value and brand image and customer satisfaction, brand image and customer satisfaction and customer loyalty are not significant at the level of 0.05. However, there are some differences of the perceptions for perceived value, brand image, customer satisfaction, and customer loyalty between male and female. It is identified that the subtle differences can be used as a demographic segmentation. Thus, marketers should focus on brand image to enhance customer loyalty through perceived value and customer satisfaction based on gender differentiation.
\end{abstract}

Keywords: Perceived value, Brand image, Customer satisfaction, Customer loyalty

\section{Introduction}

In general, cosmetic brands can vary with consumer demographic segmentation. Personal creation, skin protection, and quality of cosmetic products are very important factors for young people to consider in Korea [1]. They tend to be value maximizers, within the bounds of search costs and limited knowledge, mobility, and income. They estimate which offer will deliver the most perceived value and act on it [2].

Given the difficulty of assessing and interpreting product attributes and benefits for experience and credence goods, brands may be particularly important signals of quality and other characteristics to consumers for these types of products. As consumers' lives become more complicated, rushed, and time starved, the ability of a brand to simplify decision making and reduce risk is invaluable [3]. When comparing high- and low-priced cosmetic brands, the mean value of brand loyalty and repurchase intention of high-priced ones was higher than that of low-priced ones [4].

Although prior studies have emphasized the importance of service quality, satisfaction, perceived value, and image, the nature of the relationships that exist between these constructs and the understanding of their impact on customer behavior still remains a key issue [5]. However, little has been done to investigate the relationship of perceived value and brand image in low-priced cosmetic brands. 
A research study examining how male and female shop showed that male often needs to be invited to touch a product, whereas female is likely to pick it up without prompting. Male often likes to read product information; female may relate to a product on a more personal level [6]. Thus, it would be meaningful to examine the perceptions of men and women toward low-priced cosmetic brands. This study attempts to examine the interrelationship between perceived value, brand image, customer satisfaction, and customer loyalty in low-priced cosmetic brands from a gender perspective.

\section{Literature Review}

Customer-perceived value is the difference between the prospective customer's evaluation of all the benefits and all the costs of an offering and the perceived alternatives. The marketers can increase the value of the customer offering by raising economic, functional, or emotional benefits and/ or reducing one or more costs [2].

Recently, it has been found that consumer behaviors are more understandable when assessed through perceived value [7]. However, even if there is a perceived qualityvalue- higher price disposition relationship, this relationship may differ under a large number of circumstances caused by different types of products and different types of brands [8].

Kirmani and Zeithaml [9] suggested a model that depicts the antecedents and consequences of perceived quality as it relates to brand image. Consequences of quality include: brand attitude, perceived value, and brand image. Thus, it can be postulated that perceived value is positively associated with brand image of low-priced cosmetic brands. Literature review also show that perceived value can be an important predictor of satisfaction [10].

Brand image is a determinant affecting customers' subjective perceptions and consequent behaviors [11] and is an extrinsic cue when consumers are evaluating a product/service before purchasing [12]. The more favorable the brand image, the more positive the attitude toward the branded product and its attributes [13]. Brand image aids a consumer in recognizing his/her needs and wants regarding the brand and distinguishes the brand from other rivals [14].

Because of its ability to influence future purchase behavior, the understanding of what makes consumers to be satisfied has been found to be one of the most important issues in businesses [15]. The first influence factor of overall customer satisfaction is perceived quality and the second factor is perceived value [16]. Martenson [17] suggested that corporate brand image positively influences customer satisfaction, which leads to store loyalty. The ultimate objective of most retailers is to gain loyal customers. Loyalty can be an outcome of customer satisfaction [15]. A reasonable product/service price, a satisfactory value, and a trust in the brand will make consumers have greater intention to purchase the product/service $[18,19]$. The purpose of the research is to investigate the relationship among perceived value, brand image, customer satisfaction, and customer loyalty of low-priced cosmetic brands; we, therefore, propose the following hypotheses:

H1 Perceived value will have a positive impact on brand image.

H2 Perceived value will have a positive impact on customer satisfaction.

H3 Brand image will have a positive impact on customer satisfaction.

H4 Brand image will have a positive impact on customer loyalty.

H5 Customer satisfaction will have a positive impact on customer loyalty.

Gender identify is a social construct that associates men and women with specific characteristics such as roles, values, attitudes and behaviors [20]. Sun et al. [21] posited that gender differences exist due to biological, cognitive, behavioral and social causes. Gender differentiation has long been applied in clothing, hairstyling, cosmetics, and 
magazines. Avon, for one, has built $\$ 6$ billion-plus business selling beauty products to women. Men often like to read product information; women may relate to a product on a more personal level [2]. Thus, we propose that the difference in gender acts as a moderating effect.

H6-1 The relationship between perceived value and brand image will be moderated by gender.

H6-2 The relationship between perceived value and customer satisfaction will be moderated by gender.

H6-3 The relationship between brand image and customer satisfaction will be moderated by gender.

H6-4 The relationship between brand image and customer loyalty will be moderated by gender.

H6-5 The relationship between customer satisfaction and customer loyalty will be moderated by gender.

\section{The Research}

The research is designed to confirm the relationships among perceived value, brand image, customer satisfaction, and customer loyalty of a low-priced cosmetic brand, as well as examine the moderating effect of gender. The research model is shown in Figure 1.

A self-administered questionnaire was developed for this study. The survey included the perceptions of perceived value, brand image, and customer satisfaction and demographic information.

The study has four variables, which each has multiple items that are measured by a seven-point Likert-type scale $(1=$ strongly disagree and $7=$ strongly agree $)$. Convenience sampling drew a sample of 234 consumers who have used low-priced cosmetic brands in Korea and their ages were between 20 and 30. For data collection, a personal interview technique was used at Gyeongnam province from May 12 to 23, 2014 and of the 250 questionnaires, 16 questionnaires were eliminated because of missing data, resulting in a final sample of 234 consumers. The participants were asked to respond to the survey questionnaires based on their most recent experience of low-priced cosmetic brands.

In this study, items used to operationalize the constructs were mainly adapted from previous studies and modified in the context of the research. Five items of perceived value (overall higher value and service value compared to price, good choice, good reputation, and positive emotion) [22], five items of brand image (positive reaction of people, confident brand image, unique brand image, and desirable brand name) [23], three items of customer satisfaction (overall satisfaction with product, price, and quality) [24], and five items of customer loyalty (continuous use, positive word of mouth, recommendation, and revisit intention) [22] were modified through reviewing previous studies.

In order to test the proposed interrelationships among the perceptions of perceived value, brand image, customer satisfaction, and customer loyalty, structural equation modeling (SEM) was performed using analysis of moment structure (AMOS). Structural equation modeling allowed us to examine the causal relationships among concepts in the model and to test the model against the obtained measurement data to identify how well the proposed model fits the data [25]. SEM is an appropriate statistical method to examine hypothesized relationships among constructs proposed in this study. 


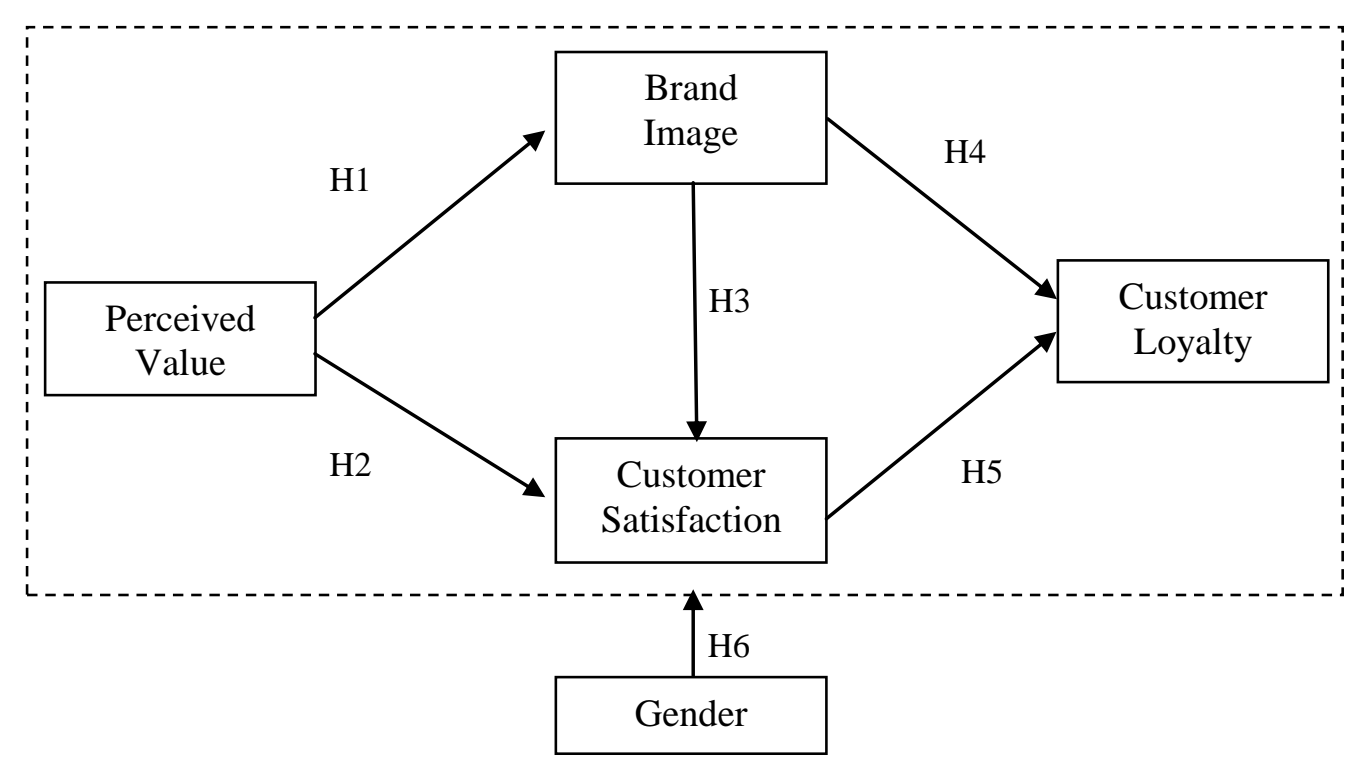

Figure 1. Research Model

\section{Findings}

Examination of demographic characteristics is as follows. Demographic characteristics with 234 respondents who have used low-priced cosmetic brands in Korea indicate that the most common respondents to be female (65.3 percent female). Most of the respondents were in the 20-30 age range. The most favorable reason for a low-priced cosmetic brand was quality compared to price.

Confirmatory factor analysis (CFA) was used to assess the psychometric properties of the measures (see Table 1). We used AMOS 18.0 with maximum likelihood estimation to assess the measurement. Except for the chi-square statistic $\left(\chi^{2}(91)=193.835, p=0.000\right)$, overall fit indices demonstrated a good fit with the data (GFI $=0.903, \mathrm{CFI}=0.953$, TLI $=$ 0.938 , RMSEA $=0.070$ ). Further, the results of the reliability test showed that the alpha values of all four constructs used in this study exceeded the minimum requirement for reliability of 0.70 , indicating that multiple measurement items were highly reliable for measuring each construct [25].

Table 1. Reliability \& Convergent Validity of Measurement Model

\begin{tabular}{|c|c|c|c|c|c|c|c|}
\hline Construct & Items & $\begin{array}{l}\text { Standardized } \\
\text { estimate }\end{array}$ & S.E. & C.R & $\begin{array}{c}\text { Composite } \\
\text { reliability }\end{array}$ & AVE & Cronbach's 0 \\
\hline \multirow{5}{*}{$\begin{array}{l}\text { Perceived } \\
\text { value }\end{array}$} & PV1 & 0.668 & & & \multirow{5}{*}{0.972} & \multirow{5}{*}{0.550} & \multirow{5}{*}{0.862} \\
\hline & PV2 & 0.746 & 0.096 & 10.869 & & & \\
\hline & PV3 & 0.724 & 0.100 & 10.513 & & & \\
\hline & PV4 & 0.831 & 0.091 & 12.048 & & & \\
\hline & PV5 & 0.728 & 0.095 & 9.673 & & & \\
\hline \multirow{4}{*}{ Brand image } & BI1 & 0.763 & & & \multirow{4}{*}{0.967} & \multirow{4}{*}{0.548} & \multirow{4}{*}{0.825} \\
\hline & BI2 & 0.769 & 0.102 & 11.418 & & & \\
\hline & $\mathrm{BI} 3$ & 0.768 & 0.098 & 11.409 & & & \\
\hline & BI5 & 0.656 & 0.093 & 9.670 & & & \\
\hline \multirow{4}{*}{$\begin{array}{l}\text { Customer } \\
\text { satisfaction }\end{array}$} & $\mathrm{CS} 1$ & 0.711 & & & \multirow{4}{*}{0.957} & \multirow{4}{*}{0.549} & \multirow{4}{*}{0.793} \\
\hline & $\mathrm{CS} 2$ & 0.647 & 0.110 & 9.299 & & & \\
\hline & CS3 & 0.879 & 0.115 & 10.756 & & & \\
\hline & CL1 & 0.806 & & & & & \\
\hline
\end{tabular}




\begin{tabular}{|c|c|c|c|c|c|c|c|}
\hline \multirow{3}{*}{$\begin{array}{l}\text { Customer } \\
\text { loyalty }\end{array}$} & CL3 & 0.822 & 0.067 & 13.740 & \multirow[b]{3}{*}{0.980} & & \\
\hline & CL4 & 0.867 & 0.083 & 12.687 & & \multirow[b]{2}{*}{0.682} & \multirow[b]{2}{*}{0.882} \\
\hline & CL5 & 0.807 & 0.069 & 13.472 & & & \\
\hline
\end{tabular}

Also, convergent validity was examined with the factor loadings in the measurement model. All confirmatory factor loadings exceeded the accepted level of 0.5 , and all factor loadings were significant at the alpha level of 0.01 [26]. As such, the results confirmed the dimensionality of the solution and suggested convergent validity in Table 1 . Furthermore, average variance extracted (AVE) of all constructs exceeded the recommended 0.5 threshold [25]. Discriminant validity was also assessed by comparing the AVE with the squared correlations between constructs [25]. All of the squared correlations between the two constructs were less than the AVEs, which suggests that the constructs were distinct (see Table 2).

Table 2. Discriminant Validity Analysis

\begin{tabular}{|c|c|c|c|c|c|c|}
\hline Construct & Average & $\begin{array}{l}\text { Standard } \\
\text { deviation }\end{array}$ & $\begin{array}{l}\text { Perceived } \\
\text { value }\end{array}$ & $\begin{array}{l}\text { Brand } \\
\text { image }\end{array}$ & $\begin{array}{l}\text { Customer } \\
\text { satisfaction }\end{array}$ & $\begin{array}{l}\text { Customer } \\
\text { loyalty }\end{array}$ \\
\hline Perceived value & 4.873 & 0.843 & 0.550 & & & \\
\hline Brand image & 4.930 & 0.964 & $0.595^{*}$ & 0.548 & & \\
\hline Customer satisfaction & 4.920 & 0.910 & $0.697^{*}$ & $0.530^{*}$ & 0.549 & \\
\hline Customer loyalty & 5.044 & 1.001 & $0.631^{*}$ & $0.656^{*}$ & $0.633^{*}$ & 0.682 \\
\hline
\end{tabular}

The path relationships within the research model were analyzed by structural equation modeling (SEM) using AMOS 18.0. The fit indices of the research model shown in Table 2 are acceptable $\left(\chi^{2}(94)=226.270, p=0.000\right.$, GFI $=0.888$, CFI $=0.940$, TLI $=0.923$, RMSEA $=0.078)$. The relationship between the perception of perceived value and brand image $(\mathrm{H} 1)$ was supported by an estimate of $0.692(\mathrm{p}=0.000)$. The relationship between the perception of perceived value and customer satisfaction (H2) was supported by an estimate of $0.748(\mathrm{p}=0.000)$. The relationship between the perception of brand image and customer satisfaction (H3) was not supported by an estimate of 0.133 ( $\mathrm{p}=0.127)$. The relationship between the perception of brand image and customer loyalty (H4) was supported by an estimate of $0.445(\mathrm{p}=0.000)$. The relationship between the perception of customer satisfaction and customer loyalty (H5) was supported by an estimate of 0.467 (p $=0.000$ ). Meanwhile, the indirect relationship between perceived value and customer loyalty was supported by an estimate of $0.707(\mathrm{p}=0.000)$ through the perception of brand image and customer satisfaction.

Table 3. Results of Hypothesis Testing

\begin{tabular}{|c|c|c|c|c|c|c|}
\hline Hypothesis & Path & Std. Estimate & S.E. & t-value & $\overline{p \text {-value }}$ & Result \\
\hline H1 & $\mathrm{PV} \rightarrow \mathrm{BI}$ & 0.692 & 0.095 & 8.180 & 0.000 & Accepted \\
\hline $\mathrm{H} 2$ & $\mathrm{PV} \rightarrow \mathrm{CS}$ & 0.748 & 0.109 & 6.661 & 0.000 & Accepted \\
\hline $\mathrm{H} 3$ & $\mathrm{BI} \rightarrow \mathrm{CS}$ & 0.133 & 0.075 & 1.528 & 0.127 & Rejected \\
\hline $\mathrm{H} 4$ & $\mathrm{BI} \rightarrow \mathrm{CL}$ & 0.445 & 0.092 & 5.634 & 0.000 & Accepted \\
\hline
\end{tabular}

Notes: $\chi^{2}(94)=226.270, p=0.000$, GFI $=0.888, \mathrm{NFI}=0.903, \mathrm{CFI}=0.940, \mathrm{TLI}=0.923, \mathrm{RMSEA}=0.078, \mathrm{PV}=$ Perceived value, $\mathrm{BI}=$ Brand image, $\mathrm{CS}=$ Customer satisfaction, $\mathrm{CL}=$ Customer loyalty 
Table 4. Moderating Effect of Gender

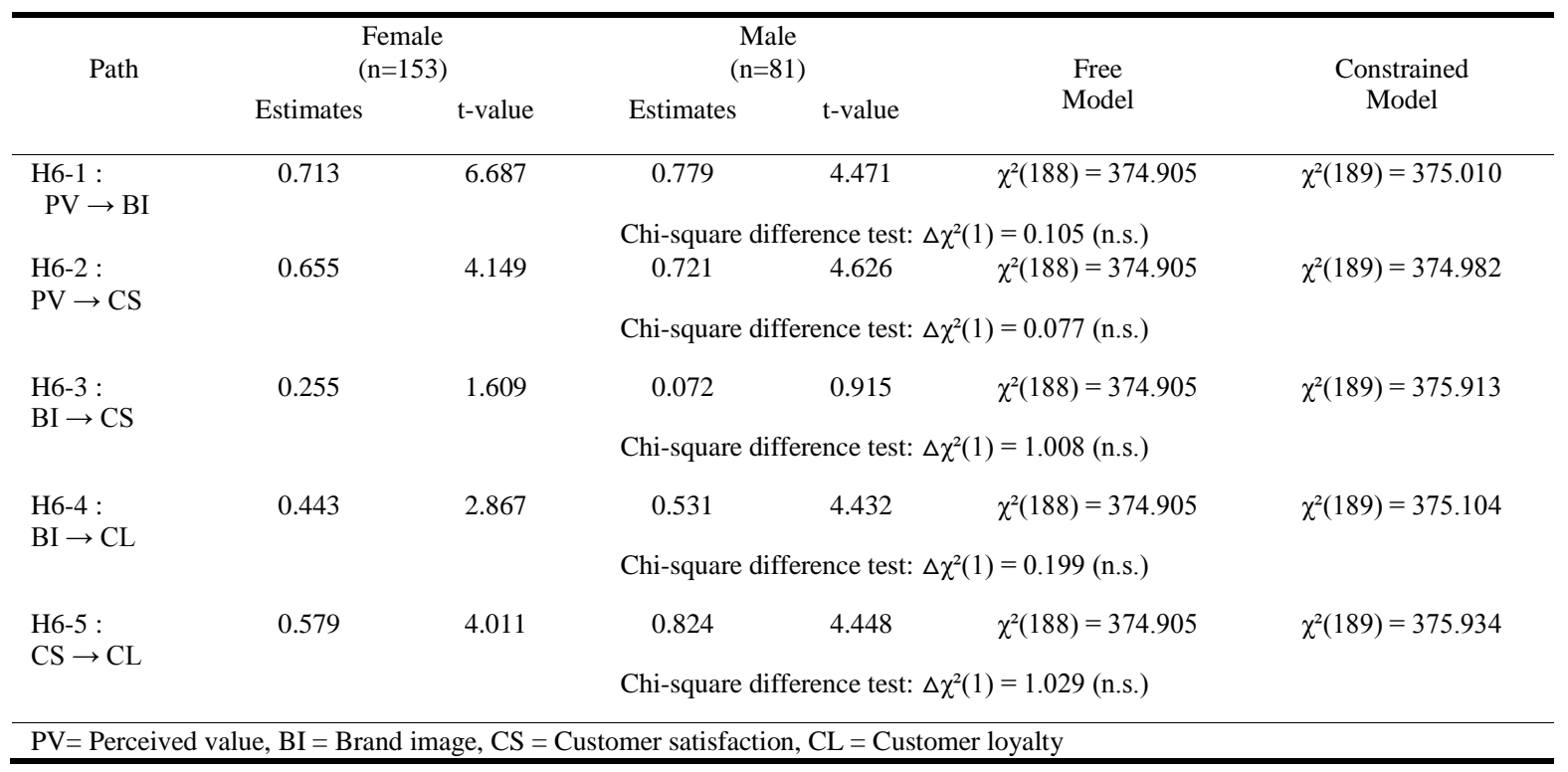

Table 4 showed that moderating effects of gender in the relationships between the constructs were not significant at the alpha level of 0.05 . When perceived value has a positive effect on brand image, men show more favorable respond. When perceived value has a positive effect on customer satisfaction, men show more favorable respond. When brand image has a positive effect on customer loyalty, men show more favorable respond. When customer satisfaction has a positive effect on customer loyalty, men show more favorable respond. This implies that young men may be interested in low-priced cosmetic brands as much as young women.

\section{Conclusions}

This study empirically tested the effects of the perception of perceived value on not only brand image but also customer satisfaction, the effects of brand image on customer satisfaction and customer loyalty, and the effect of customer satisfaction on customer loyalty in low-priced cosmetic brands of South Korea. The moderating role of gender in the relationships between the constructs was not identified. The main findings indicated that perceived value could influence customer loyalty in an indirect way through brand image and customer satisfaction. Thus, it is expected that brand image can play an important role in enhancing customer loyalty of low-priced cosmetic brands through perceived value. The reality is that product quality of a low-priced brand is often highly ambiguous and difficult without a great deal of prior experience and expertise. In such cases, consumers will use brand image or heuristic they can come up with to make their decisions in the best manner possible.

The findings suggested that perceived value of low-priced cosmetic brands is positively associated with brand image and customer satisfaction and customer loyalty including revisiting intention, positive word of mouth, and willingness to recommend. These results confirmed to previous studies identifying the relationship of perceived value and customer loyalty [22]. This study revealed that brand image and customer satisfaction are very important factors for inducing more positive customer loyalty. These results were consistent with the findings of past studies verifying the relationship between brand image and customer loyalty [17]. On the contrary, it was identified that brand image could not influence customer satisfaction with low-priced cosmetic brands. This implies that self- 
image congruity is a good predictor variable of consumers' brand preferences and consumer satisfaction [27].

Besides confirming the findings of previous studies, this study uniquely contributed to brand image literature. Today, consumers can find a lot of information about products, prices and stores through the internet. As a result of their increased awareness, they are likely to become more price sensitive [28]. Thus, this study suggested that the perception of image of a low-priced cosmetic brand can be positively associated with customer loyalty. In addition, while a previous study has focused on perceived value-loyalty intentions link [22], this research extended the literature by suggesting that the relationship between perceived value and customer loyalty is mediated by brand image and customer satisfaction.

The findings of this study should be interpreted with caution because there are some limitations. First, deriving more generalized results would likely require applying the same model in other provinces of South Korea. Second, consumers' attitudes to-ward perceived value can vary over time. Such bias in the sample might influence the results. It would be meaningful to conduct the same study in another time point and compare the results. Third, our study examined and proved the significant role of perceived value on brand image, customer satisfaction, and customer loyalty; however, as previous studies have revealed, other motivation could be the reason behind an individual to be satisfied with low-priced cosmetic brands.

\section{References}

[1] J. H. Hyun and T. G. Choo, "A Study on Purchasing Behaviors of Budget-Priced Cosmetics”, Journal of the Korean Society of Clothing Industry, vol. 7, no. 6, (2005), pp. 617-623.

[2] P. Kotler and K. L. Keller, "Marketing Management 14ed", Pearson, New York, (2012).

[3] K. L. Keller, "Strategic Brand Management: Building, Measuring, and Managing Brand Equity 3ed", Pearson, New York, (2008)b

[4] E. J. Bae and H. W. Sung, "The Effects of Price Perception and Product Attributes on Brand Loyalty and Repurchase Intention: Comparisons between High Priced and Low Priced Cosmetic Brand", Korean Journal of Human Ecology, vol. 23, no. 2, (2014), pp. 303-316.

[5] H. H. Hu, J. Kandampully and T. D. Juwaheer, "Relationship and Impacts of Service Quality, Perceived Value, Customer Satisfaction, and Image: An Empirical Study", The Service Industrial Journal, vol. 29, no. 2, (2009), pp. 111-125.

[6] R. J. Fisher and L. Dube, "Gender Differences in Responses to Emotional Advertising: A Social Desirability Perspective", Journal of Consumer Research, vol. 31, no. 4, (2005), pp. 850-858.

[7] J. L. Heskett, W. E. Sasser and L. A. Schlesinger, "The Service Profit Chain”, How Leading Companies Link Profit and Growth to Loyalty, Satisfaction, and Value, The Free Press, (1997).

[8] J. Vera, "Perceived Brand Quality as a Way to Superior Customer Perceived Value Crossing by Moderating Effects", Journal of Product \& Brand Management, vol. 24, no. 2, (2015), pp. 147-156.

[9] A. Kirmani and V. Zeithaml, "Advertising, Perceived Quality, and Brand Image”, In D. A. Aaker and A. Biel (ed), Brand Equity \& Advertising: Advertising's Role in Building Strong Brand, Psychology Press, (1993), pp.143-154.

[10] T. Dmitrovic, K. C. Ljubica, T. Kolar, M. M. Brencic, I. Ograjensek and V. Zabkar, "Conceptualizing Tourist Satisfaction at the Destination Level", International Journal of Culture, Tourism and Hospitality Research, vol. 3, no. 2, (2009), pp.116-126.

[11] K. Ryu, H. Han and T. H. Kim, "The Relationships among Overall Quick-Causal Restaurant Image, Perceived Value, Customer Satisfaction, and Behavioral Intentions", International Journal of Hospitality Management, vol. 27, no. 3, (2008), pp. 459-469.

[12] V. A. Zeithaml, "Consumer Perceptions of Price, Quality, and Value: A Means-End Model and Synthesis of Evidence", Journal of Marketing, vol. 52, no. 3, (1988), pp. 2-22.

[13] M. A. Simonian, S. Forsythe, W. S. Kwon and V. Chattaraman, "The Role of Product Brand Image and Online Store Image on Perceived Risks and Online Purchase Intentions for Apparel”, Journal of Retailing and Consumer Services, vol. 19, no. 3, (2012), pp. 325-331.

[14] A. Anwar, A. Gulzar, F. B. Sohail and S. N. Akram, "Impact of Brand Image, Trust, and Affect on Consumer Brand Extension Attitude: The Mediating Role of Brand Loyalty", International Journal of Economics and Management Sciences, vol. 1, no. 5, (2011), pp. 73-79.

[15] R. L. Oliver, "Satisfaction: A Behavioral Perspective on the Consumer", McGraw-Hill, New York, NY, (1997). 
[16] J. J. Cronin Jr., M. K. Brady and G. T. M. Hult, "Assessing the Effects of Quality, Value, and Customer Satisfaction on Consumer Behavioral Intention in Service Environments", Journal of Retailing, vol. 76, no. 2, (2000), pp. 193-218.

[17] R. Martenson, "Corporate Brand Image, Satisfaction and Store Loyalty: A Study of the Store as a Brand, Store Brands and Manufacturer Brands", International Journal of Retail \& Distribution Management, vol. 35, no. 7, (2007), pp. 544-555.

[18] W. B. Dodds, K. B. Monroe, and D. Grewal, "Effects of Price, Brand, and Store Information on Buyers' Product Evaluations", Journal of Marketing Research vol. 28, no. 3, (1991), pp. 307-319.

[19] H. W. Kim, Y. Xu and S. Gupta, "Which Is More Important in Internet Shopping, Perceived Price or Trust?", Electronic Commerce Research and Applications, vol. 11, no. 3, (2012), pp. 241-252.

[20] K. M. Palan, "Gender Identify in Consumer Behavior Research: A Literature Review and Research Agenda”, Academy of Marketing Science Review vol. 20, no. 10, (2001), pp. 1-26.

[21] Y. Sun, K. H. Lin, C. H. Jiang, J. Z. Peng and X. Chen, "Do Males and Females Think in the Same Way?", An Empirical Investigation on the Gender Differences in Web Advertising Evaluation', Computers in Human Behavior, vol. 26, no. 6, (2010), pp. 1614-1624.

[22] A. Floh, A. Zauner, M. Koller and T. Rusch, "Customer Segmentation Using Unobserved Heterogeneity", Journal of Business Research, vol. 67, (2014), pp. 974-982.

[23] A. Subramaniam, A. A. Mamun, P. Y. Permarupan and N. R. B. Zainol, "Effects of Brand Loyalty, Image and Quality on Brand Equity: A Study among Bank Islam Consumers In Kelantan, Malaysia”, Asian Social Science, vol. 10, no. 14, (2014), pp. 67-73.

[24] S. Ene and B. Ozkaya, "A Study on Corporate Image, Customer Satisfaction and Brand Loyalty in the Context of Retail Store”, Asian Social Science vol. 10, no. 14, (2014), pp. 52-66.

[25] J. F. Hair, R. E. Anderson, R. L. Tatham and W. C. Black, "Multivariate Data Analysis 5th Ed. Prentice Hall”, Upper Saddle River, NJ, (1998).

[26] J. C. Anderson and D. W. Gerbing, "Structural Modeling in Practice: A Review and Recommended Two Step Approach", Psychological Bulletin, vol. 103, no. 3, (1988), pp. 411-423.

[27] A. Jamal and M. M. H. Goode, "Consumers and Brands: A Study of the Impact of Self-Image Congruence on Brand Preference and Satisfaction”, Marketing Intelligence \& Planning, vol. 19, no. 7, (2001), pp. 482-492.

[28] D. Grewal, R. Krishnan, J. Baker and N. Borin, 'The Effect of Store Name, Brand Name and Price Discounts on Consumers' Evaluations and Purchase Intention”, Journal of Retailing, vol. 74, no. 3, (1998), pp. 331-352.

[29] K. H. Chung, J. E. Yu and J. I. Shin, "The Relationship among Perceived Value, Brand Image, Customer Satisfaction, and Customer Loyalty: The Moderating Effect of Gender", Proceedings of the $3^{\text {rd }}$ International Congress on Interdisciplinary Behavior \& Social Science, (2014); Bali, Indonesia.

[30] K. H. Chung, J. E. Yu, W. J. Kim and J. I. Shin, "The Effect of Perceived Value on Customer Loyalty in a Low-Priced Cosmetic Brand of South Korea: The Moderating Effect of Gender", Advanced Science and Technology Letters, vol. 114, (2015), pp. 40-44.

Authors

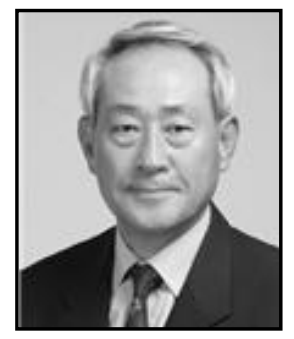

Ki-Han Chung, He is a Professor of Department of Business Administration at Gyeongsang National University, Jinju, South Korea. He received his Ph.D. in Management from Pusan National University, South Korea. His current research interests include marketing channel, market orientation, internal marketing, internet marketing, and service marketing. He has published papers in journals such as Journal of Korean Distribution and Management, Korea Logistics Review, Asia Pacific Journal of Marketing and Logistics, International Journal of Business and Information, Korean Journal of Tourism Research, The Journal of Internet Electronic Commerce Research, The Academy of Customer Satisfaction Management, Journal of the Korea Entrepreneurship, Journal of Industrial Economics and Business, International Journal of Information Management, INFORMATION (Japan), and ICIC Express Letters, Part B: Applications 


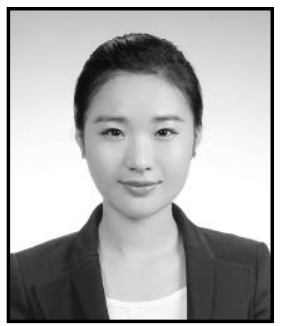

Ji-Eun Yu, She is a Master of Department of Business Administration at Gyeongsang National University, Jinju, South Korea. Her current research interests include marketing channel, internet marketing, SNSs marketing, and service marketing.

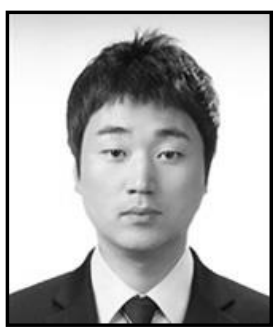

Wonjong Kim, He is a candidate for Ph. D. in the Department of Business Administration at Gyeongsang National University, Jinju, South Korea. He had finished Standard MBA course in Ateneo Graduate School of Business in the Philippines. His current research interests include CSR activities, e-commerce, internet marketing, and market orientation. He has published papers in journals such as The Journal of Internet Electronic Commerce Research, Asia Pacific Journal of Information Systems, and Korean Business Education Review.

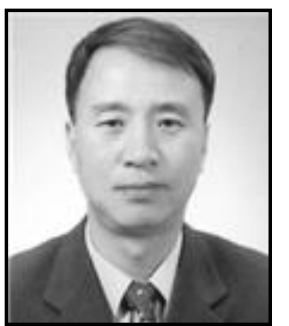

Jae-Ik Shin, He is a Professor of Department of E-Business at Gyeongnam National University of Science and Technology, South Korea. He received his Ph.D. in Management from Gyeongsang National University, South Korea. His current research interests include internet marketing, tourism marketing, corporate social responsibility, and service marketing. He has published papers in journals such as International Journal of Information Management, INFORMATION (Japan), ICIC Express Letters, Part B: Applications, Asia Pacific Journal of Marketing and Logistics, Korean Journal of Tourism Research, The Journal of Internet Electronic Commerce Research, The Academy of Customer Satisfaction Management, International Journal of Business and Information, Journal of the Korea Entrepreneurship, and International Journal of u- and e-Service, Science and Technology. 
International Journal of $u-$ and e- Service, Science and Technology Vol.9, No. 2 (2016) 